\title{
Study of the Strength Geopolymer Concrete with Alkaline Solution of Varying Molarity
}

\author{
A.Maria Rajesh ${ }^{1}$, M.Adams Joe ${ }^{2}$, Roy Mammen ${ }^{3}$ \\ ${ }^{1}$ Assistant Professor, Dept. of Civil Engineering, ACEW, Nagercoil, Tamilnadu, India. \\ ${ }^{2}$ Associate Professor, Dept. of Civil Engineering, TREC, Nagercoil, Tamilnadu, India. \\ ${ }^{3}$ Director of Quality Assurance, Dept. Of Built Environment Engineering, Muscat College, Oman.
}

\begin{abstract}
Manufacture of Portland cement produces large of volumes of carbon dioxide and other gases. Releasing these gases causes atmospheric pollution and subsequent environmental degradation. Finding a suitable alternative solution to mitigate the environmental degradation caused by using Portland cement is very important for environmental sustainability. The use of geopolymer concrete as an alternative material over Portland cement concrete to reduce the adverse effects on the environment is investigated in this paper. The paper also critically analyses the economic and environmental benefits of geopolymer concrete and address the financial and environmental issues associated with the production and use of Portland cement. Geopolymer cement utilizes industrial waste materials such as fly ash from thermal power stations to provide a practical solution to waste management as well as environmental protection methods.

Geopolymer concrete products are known to possess far better durability and strength properties than Portland cement concrete. These properties are investigated extensively in laboratory to verify and confirm the superior durability and strength properties. The paper also discusses the factors which restrict the use of geopolymer concrete as an alternative to Portland cement concrete. Laboratory tests are conducted on compressive strength, split tensile strength and flexural tests for specimens with combination of different molarity. The results obtained are compared analytically and graphically
\end{abstract}

Keywords: - GPC, Low calcium flyash, GGBS, steel fibres, Alkaline liquid, compressive strength, split tensile strength and flexural Strength

\section{INTRODUCTION}

The term geopolymer was first introduced by Davidovits in 1978 to represent the mineral polymers resulting from geochemistry. Geopolymers are the alkali aluminosilicates binders formed by the alkali silicate activation of aluminosilicates materials (Duxson, et al., 2005). They were mostly synthesised from silicon and aluminium materials of geological origin. However, nowadays, geopolymers are manufactured from secondary raw materials such as fly ash and slag. The use of fly ash has potential ecological benefits and much lower cost than other source materials (Buchwald et al, 2009).

Geopolymer concrete has emerged as a new engineering material with the potential to form an important contributor towards environmentally sustainable construction and building products industry. Geopolymers are alkali-activated aluminosilicates, with a much lower carbon dioxide emission than ordinary Portland cements (Duxson et al, 2007). Industrial aluminosilicates waste materials such as coal ash and blast furnace slag are activated by alkali to form geopolymers. As reported by Duxson et al, geopolymers demonstrate improved strength and chemical properties in addition to many other characteristics which are potentially valuable.

Depending on the selected raw material and processing conditions, geopolymer concrete exhibit a variety of diverse properties, including high compressive strength, low shrinkage, fast or slow setting, acid resistance, fire resistance and low thermal conductivity (Dusxon et al, 2006). The manufacture of geopolymer concrete is carried out using the usual concrete technology methods. The geopolymer paste binds loose aggregates and unreacted materials together to form geopolymer concrete. The concrete can be produced with or without the use of admixtures. As in the case of Ordinary Portland Cement (OPC), the aggregates occupy 75-80\% by mass of geopolymer concrete (Hardjito \& Rangan, 2005).

Geopolymeric materials made from coal ash can have better chemical and mechanical properties than Ordinary Portland Cement products. Early researches have shown that geopolymers can be produced cheaply and can be made when naturally occurring materials are mixed with $\mathrm{NaOH}$ and water (Kostas et al, 2007).

\subsection{Objectives}

The objectives of this paper are as follows

- To understand properties of geopolymer concrete in order to use it as alternative for Ordinary Portland Cement. 
- To establish the economical, technological and environmental benefits of geopolymer binders over Ordinary Portland Cement.

- To verify the improvement of properties like compressive strength, tensile strength, flexural strength etc by using geopolymer binders instead of OPC.

- To draw conclusion on whether geopolymer technology can provide an appropriate alternative for Portland cement.

\subsection{Properties and Application of geopolymer Concrete}

Application of geopolymer concrete technology is showing great promise to contribute positively to a sustainable concrete industry. Work conducted by Duxson et al (2007) indicated that, depending on the synthesis conditions (including nature of start materials), geopolymer concrete can be made to achieve the following properties:

$>$ High compressive strength gain

$>$ Good abrasion resistance

$>$ Rapid controllable setting and hardening

$>$ Fire resistance (up to $1000^{\circ} \mathrm{C}$ ) and no emission of toxic fumes whenheated.

$>$ High level of resistance to a range of different acids and salt solutions

$>$ Not subject to deleterious alkali-aggregate reactions

$>$ Low shrinkage and low thermal conductivity

$>$ Adhesion to fresh and old concrete substrate, steel, glass, ceramics

$>$ High surface definition that replicates mould patterns

\section{MATERIALS USED}

Following materials were used for laboratory.

$>$ Fly ash

$>$ Fine aggregate

$>$ Coarse aggregate

$>$ Alkaline liquid: Sodium hydroxide $(\mathrm{NaOH})$

$>$ Gypsum

$>$ Super plasticizer

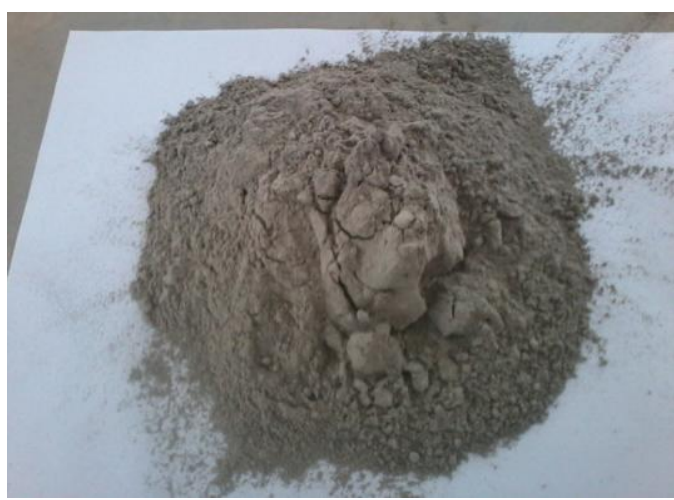

Figure.2.1 Fly Ash

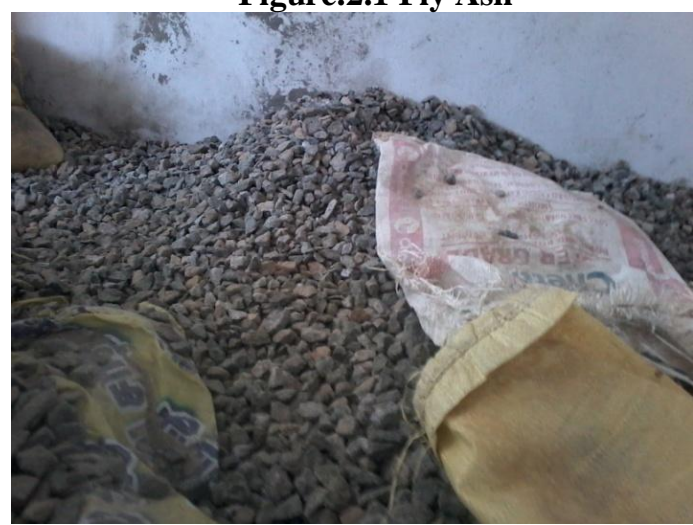

Figure.2.3 Coarse Aggregate

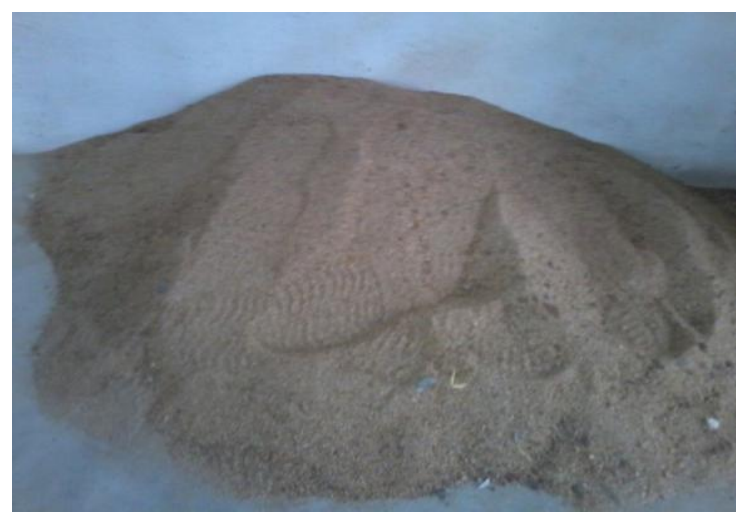

Figure.2.2 Fine Aggregate

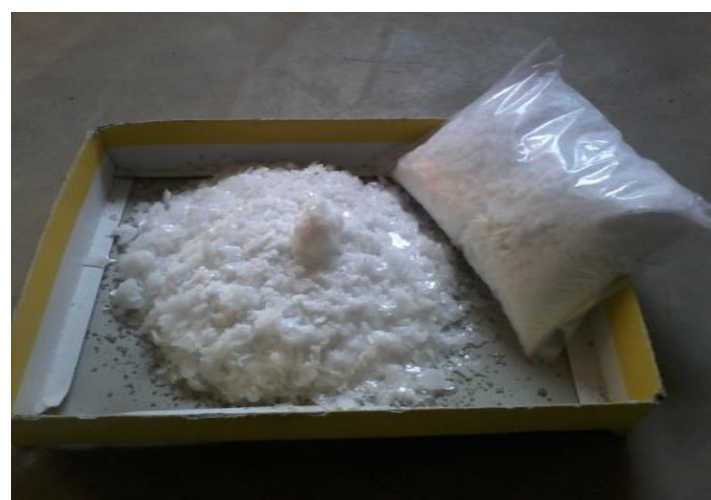

Figure.2.4 NaOH Pellets 


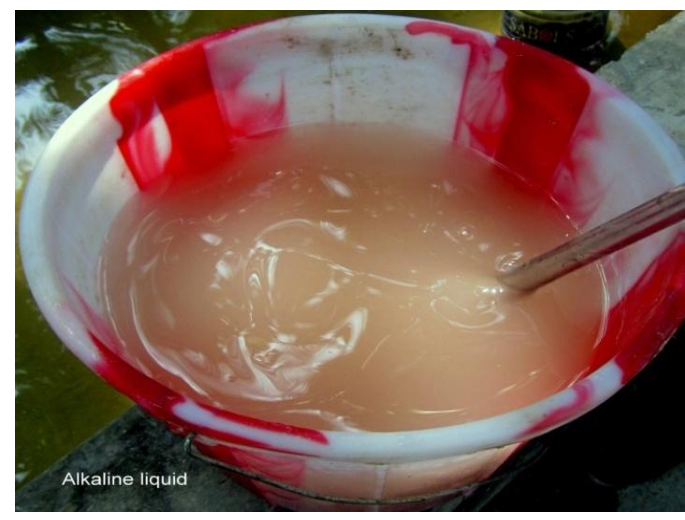

Figure.2.5 Alkaline Solution

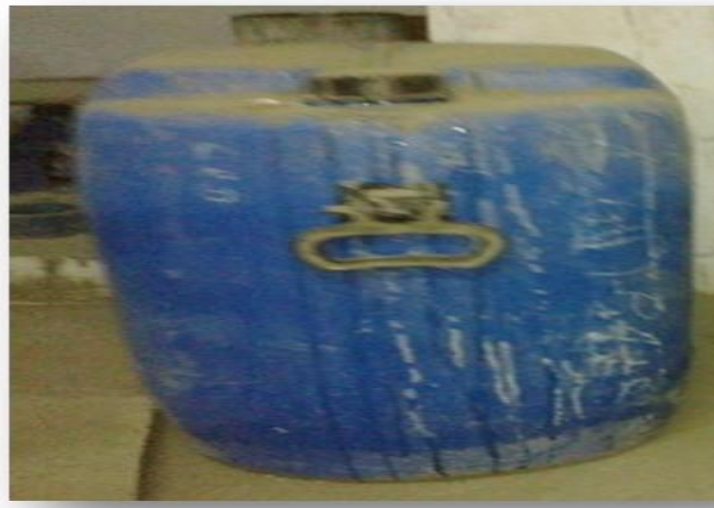

Figure. 2.6 $\mathrm{Na}_{2} \mathrm{SiO}_{3}$ Solution

\section{EXPERIMENTAL WORK}

The following tests were conducted on the ingredients of concrete and tabulated in the tables $1,2,3 \& 4$.

3.1. Mix proportion

By trial mix method, with varying proportion of Alkaline solution and flyash the following weight of ingredients were obtained

Table: 1 Constituents of geopolymer concrete $\left(\right.$ per $\left.1 \mathrm{~m}^{3}\right)$

\begin{tabular}{|c|c|c|c|c|c|c|c|c|c|c|}
\hline \multirow[b]{2}{*}{ Mix } & \multirow[b]{2}{*}{$\begin{array}{l}\text { Fly ash } \\
\mathrm{kg} / \mathrm{m}^{3}\end{array}$} & \multirow{2}{*}{$\begin{array}{l}\text { Fine } \\
\text { agg. } \\
\frac{\mathrm{Kg} /}{\mathrm{m}^{3}}\end{array}$} & \multirow[b]{2}{*}{$\begin{array}{c}\text { Coarse } \\
\text { agg. } \\
\mathrm{Kg} / \mathrm{m}^{3}\end{array}$} & \multicolumn{2}{|c|}{$\mathrm{NaOH}$ Solution } & \multirow[b]{2}{*}{$\begin{array}{c}\begin{array}{c}\text { Sodium } \\
\text { silicate }\end{array} \\
\mathrm{Kg} / \mathrm{m}^{3}\end{array}$} & \multirow{2}{*}{$\begin{array}{l}\text { Sodium } \\
\text { silicate/ } \\
\text { Sodium } \\
\text { hydroxide }\end{array}$} & \multirow{2}{*}{$\begin{array}{l}\text { (Sodium } \\
\text { silicate+ } \\
\text { Sodium } \\
\text { hydroxide)/ } \\
\text { Fly ash }\end{array}$} & \multirow[b]{2}{*}{$\begin{array}{c}\text { Gypsum } \\
(3 \%) \\
\mathrm{Kg} / \mathrm{m}^{3}\end{array}$} & \multirow{2}{*}{$\begin{array}{c}\text { Steel } \\
\text { Fibre } \\
\text { (Adding } \\
1 \% \text { ) } \\
\mathrm{Kg} / \mathrm{m}^{3}\end{array}$} \\
\hline & & & & Molarity & $\begin{array}{l}\text { Mass } \\
\mathrm{Kg} / \mathrm{m}^{3}\end{array}$ & & & & & \\
\hline M1 & 428.6 & 540 & 1260 & $8 \mathrm{M}$ & 48.97 & 122.43 & 2.5 & 0.40 & 12.86 & 4.28 \\
\hline $\mathrm{M} 2$ & 428.6 & 540 & 1260 & $10 \mathrm{M}$ & 48.97 & 122.43 & 2.5 & 0.40 & 12.86 & 4.28 \\
\hline M3 & 428.6 & 540 & 1260 & $12 \mathrm{M}$ & 48.97 & 122.43 & 2.5 & 0.40 & 12.86 & 4.28 \\
\hline M4 & 428.6 & 540 & 1260 & $14 \mathrm{M}$ & 48.97 & 122.43 & 2.5 & 0.40 & 12.86 & 4.28 \\
\hline M5 & 428.6 & 540 & 1260 & $16 \mathrm{M}$ & 48.97 & 122.43 & 2.5 & 0.40 & 12.86 & 4.28 \\
\hline
\end{tabular}

From the experimental results it was found that the Optimum compressive strength is obtained in of mix.3(12M) was found to be $40.58 \mathrm{Mpa}$ for 28 days after ambient curing The results are tabulated and graphically shown as under.

Table: 2 Workability and Compressive strength properties

\begin{tabular}{|c|c|c|c|c|c|c|c|c|c|}
\hline \multirow[b]{2}{*}{ Mix } & \multirow{2}{*}{$\begin{array}{l}\text { Molarity } \\
\text { of NaoH } \\
\text { solution }\end{array}$} & \multirow{2}{*}{$\begin{array}{c}\text { SuperP1 } \\
\text { asticizer } \\
(\%)\end{array}$} & \multirow[b]{2}{*}{$\begin{array}{c}\text { Slump } \\
\mathrm{mm}\end{array}$} & \multirow[b]{2}{*}{$\begin{array}{l}\text { Curing } \\
\text { method }\end{array}$} & \multirow[b]{2}{*}{ Curing } & \multicolumn{4}{|c|}{ Average comp. strength in $\mathrm{N} / \mathrm{mm}^{2}$} \\
\hline & & & & & & 1 day & 7 days & 14 days & 28 days \\
\hline M1 & $8 \mathrm{M}$ & 5 & 35 & Ambient & $\begin{array}{c}1,7,14 \& \\
28 \text { days }\end{array}$ & 20.52 & 25.5 & 29.45 & 32.23 \\
\hline $\mathrm{M} 2$ & $10 \mathrm{M}$ & 5 & 55 & Ambient & $\begin{array}{c}1,7,14 \& \\
28 \text { days }\end{array}$ & 22.15 & 27.55 & 32.15 & 38.55 \\
\hline M3 & $12 \mathrm{M}$ & 5 & 100 & Ambient & $\begin{array}{c}1,7,14 \& \\
28 \text { days }\end{array}$ & 23.58 & 28.14 & 33.24 & 40.58 \\
\hline M4 & $14 \mathrm{M}$ & 5 & 130 & Ambient & $\begin{array}{c}1,7,14 \& \\
28 \text { days }\end{array}$ & 22.98 & 27.95 & 33.10 & 39.67 \\
\hline M5 & $16 \mathrm{M}$ & 5 & 145 & Ambient & $\begin{array}{c}1,7,14 \& \\
28 \text { days }\end{array}$ & 21.58 & 26.78 & 31.25 & 37.55 \\
\hline
\end{tabular}

Chart1: Compressive Strength in $\mathrm{N} / \mathrm{mm}^{2}$ 


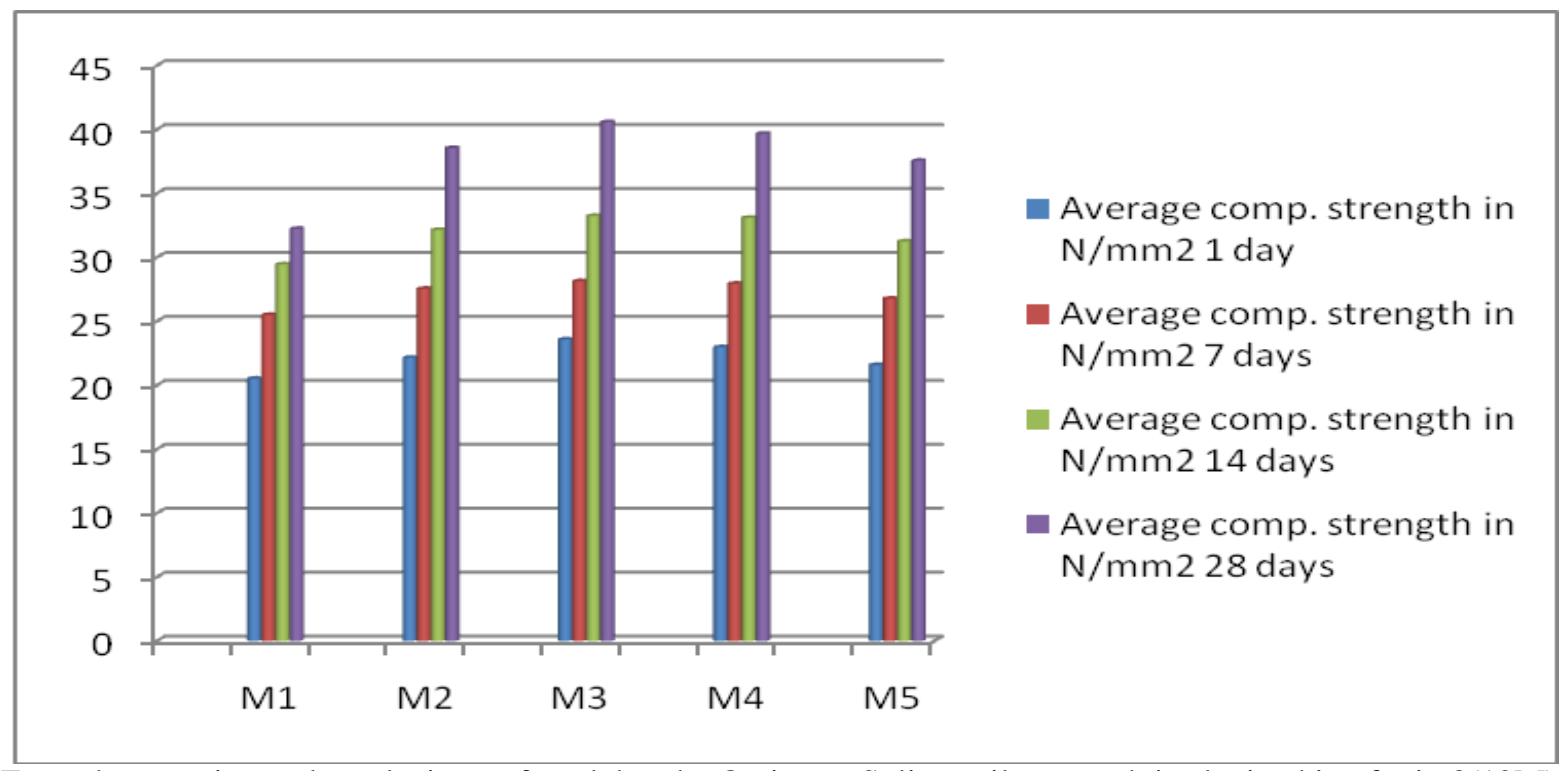

From the experimental results it was found that the Optimum Split tensile strength is obtained in of mix.3(12M) was found to be $4.23 \mathrm{Mpa}$ for 28 days after ambient curing The results are tabulated and graphically shown as under.

Table: 3 Workability and Split tensile strength properties

\begin{tabular}{|c|c|c|c|c|c|c|c|c|c|}
\hline \multirow{2}{*}{ Mix } & \multirow{2}{*}{$\begin{array}{l}\text { Molarity } \\
\text { of NaoH } \\
\text { solution }\end{array}$} & \multirow{2}{*}{$\begin{array}{c}\text { SuperPl } \\
\text { asticizer } \\
(\%)\end{array}$} & \multirow{2}{*}{$\underset{\mathrm{mm}}{\text { Slump }}$} & \multirow{2}{*}{$\begin{array}{l}\text { Curing } \\
\text { method }\end{array}$} & \multirow{2}{*}{ Curing } & \multicolumn{4}{|c|}{ Split tensile strength in $\mathrm{N} / \mathrm{mm}^{2}$} \\
\hline & & & & & & $1 \mathrm{day}$ & 7 davs & 14 dav & 28 days \\
\hline M1 & $8 \mathrm{M}$ & 5 & 35 & Ambient & $\begin{array}{c}1,7,14 \& \\
28 \text { days }\end{array}$ & 1.90 & 2.50 & 2.85 & 3.58 \\
\hline M2 & $10 \mathrm{M}$ & 5 & 55 & Ambient & $\begin{array}{c}1,7,14 \& \\
28 \text { days }\end{array}$ & 2.10 & 2.22 & 3.00 & 4.01 \\
\hline M3 & $12 \mathrm{M}$ & 5 & 100 & Ambient & $\begin{array}{c}1,7,14 \& \\
28 \text { days }\end{array}$ & 1.78 & 2.67 & 3.03 & 4.23 \\
\hline M4 & $14 \mathrm{M}$ & 5 & 130 & Ambient & $\begin{array}{c}1,7,14 \& \\
28 \text { days }\end{array}$ & 2.5 & 2.98 & 3.80 & 3.90 \\
\hline M5 & $16 \mathrm{M}$ & 5 & 145 & Ambient & $\begin{array}{c}1,7,14 \& \\
28 \text { days }\end{array}$ & 2.23 & 2.75 & 3.15 & 3.2 \\
\hline
\end{tabular}

Chart2: Split tensile Strength in N/mm ${ }^{2}$

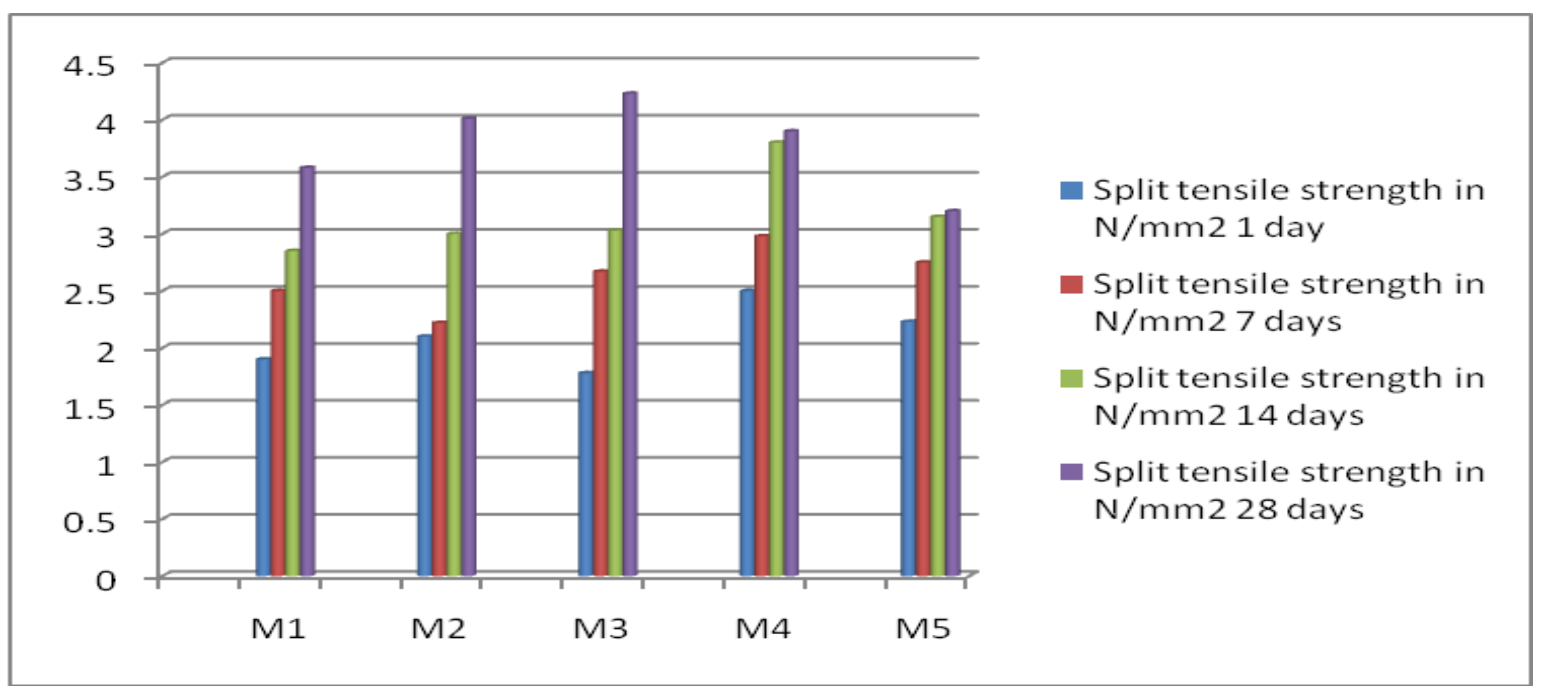


From the experimental results it was found that the Optimum Flexural strength is obtained in of mix.3(12M) was found to be $5.45 \mathrm{Mpa}$ for 28 days after ambient curing The results are tabulated and graphically shown as under.

Table: 4 Workability and Flexural strength properties

\begin{tabular}{|c|c|c|c|c|c|c|c|c|c|}
\hline \multirow{2}{*}{ Mix } & \multirow{2}{*}{$\begin{array}{c}\text { Molarity } \\
\text { of NaoH } \\
\text { solution }\end{array}$} & \multirow{2}{*}{$\begin{array}{l}\text { SuperP1 } \\
\text { asticizer } \\
(\%)\end{array}$} & \multirow{2}{*}{$\begin{array}{c}\text { Slump } \\
\mathrm{mm}\end{array}$} & \multirow{2}{*}{$\begin{array}{l}\text { Curing } \\
\text { method }\end{array}$} & \multirow{2}{*}{ Curing } & \multicolumn{4}{|c|}{ Flexural strength in $\mathrm{N} / \mathrm{mm}^{2}$} \\
\hline & & & & & & 1 day & 7 days & 14 days & 28 days \\
\hline M1 & $8 \mathrm{M}$ & 5 & 35 & Ambient & $\begin{array}{c}1,7,14 \& 28 \\
\text { days }\end{array}$ & 1.98 & 3.02 & 4.05 & 5.15 \\
\hline $\mathrm{M} 2$ & $10 \mathrm{M}$ & 5 & 55 & Ambient & $\begin{array}{c}1,7,14 \& 28 \\
\text { days }\end{array}$ & 2.05 & 3.25 & 4.15 & 5.32 \\
\hline M3 & $12 \mathrm{M}$ & 5 & 100 & Ambient & $\begin{array}{c}1,7,14 \& 28 \\
\text { days }\end{array}$ & 2.34 & 3.52 & 4.21 & 5.45 \\
\hline M4 & $14 \mathrm{M}$ & 5 & 130 & Ambient & $\begin{array}{c}1,7,14 \& 28 \\
\text { days }\end{array}$ & 2.85 & 3.10 & 4.13 & 5.40 \\
\hline M5 & $16 \mathrm{M}$ & 5 & 145 & Ambient & $\begin{array}{c}1,7,14 \& 28 \\
\text { days }\end{array}$ & 2.65 & 3.02 & 4.10 & 5.35 \\
\hline
\end{tabular}

Chart3: Flexural Strength in $\mathrm{N} / \mathrm{mm}^{2}$

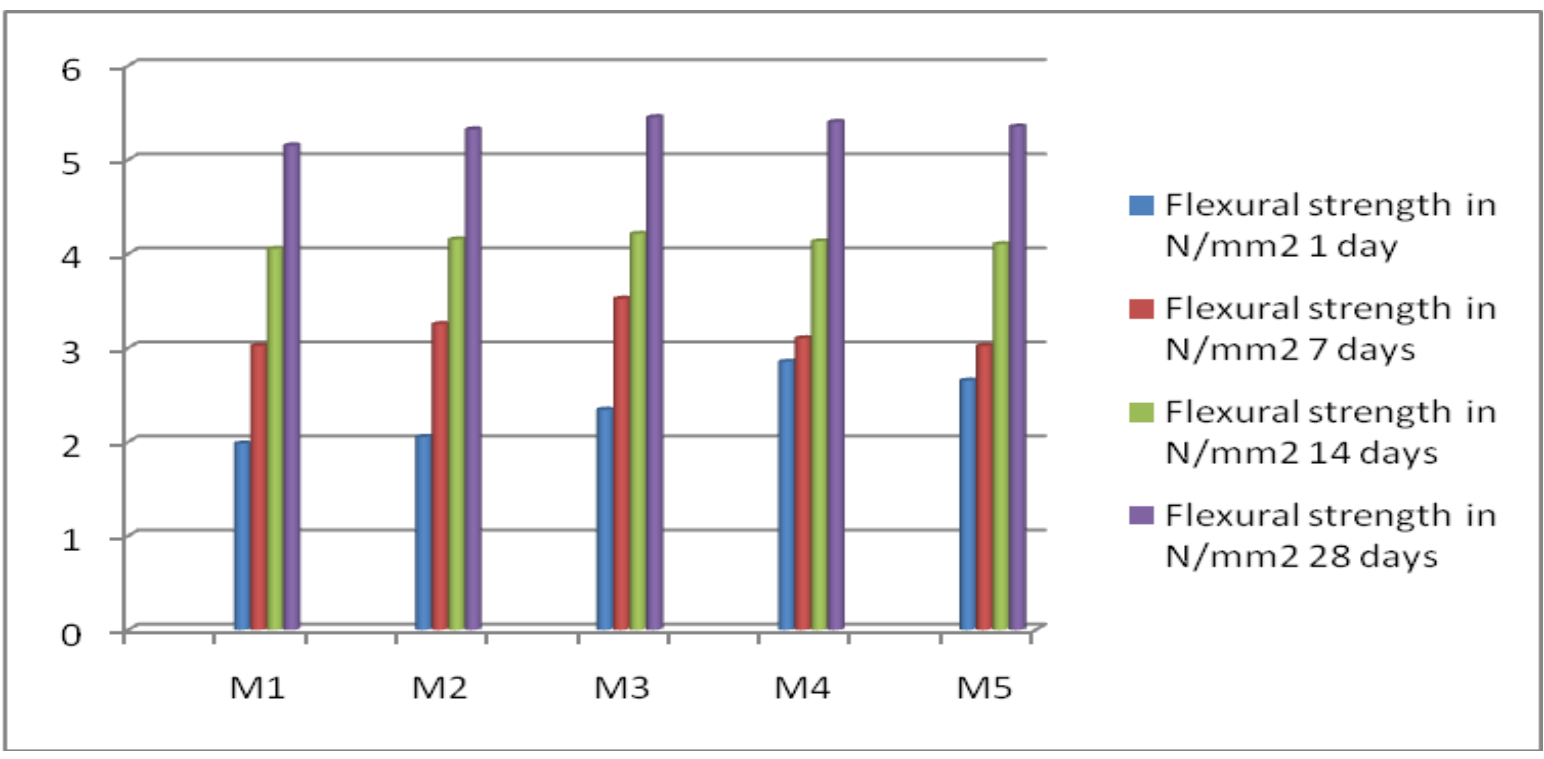

IV. CONCLUSION

The compressive strength of GPC specimens with $12 \mathrm{M}$ is 1.25 times more than that of GPC with other molarities after 28 days of hot curing

$>$ The split tensile strength of GPC specimens with $12 \mathrm{M}$ is 1.18 times more than that of GPC with other molarities after 28 days of hot curing

> The Flexural strength of GPC specimens with $12 \mathrm{M}$ is 1.058 times more than that of GPC with other molarities after 28 days of hot curing

$>$ Geopolymer technology does not only contribute to the reduction of greenhouse gas emissions but also reduces disposal costs of industrial waste.

$>$ Geopolymer technology encourages recycling of waste and finally it will be an important step towards sustainable concrete industry.

\section{REFERENCES}

[1] A.Buchwald, M.Hohmann, K.Posern, \& E.Brendler. (2009). The suitabilit of thermally activated illite/smectite clay as raw material for geopolymer binders. Applied Clay science, 300-304.

[2] D.Hardjito, \& B.V.Rangan. (2005). Developments and properties of low-calcium fly ash-based geopolymer concrete. Research Report GC1 Curtin University of Technology .

[3] Davidovits, J. (1994). Global warming impact on the cement and aggregate industry, Vol.6, No.2,pp 263-278. 
[4] Drechsler, M., \& Graham, A. (2005). Bringing resource sustainability to construction and mining industries. Innovative materials technology .

[5] Duxson, P., L.Provis, J., C.Lkey, G., W.Mallicoat, S., M.Kriven, W., \& Deventer, J. S. (2005). Understanding the relationship between geopolymer composition, microstructure and mechanical properties. Science@Direct, 47-58.

[6] A.Mariarajesh,Dr.C.Selvamony,Dr.T.R.Sethuraman and M.Shaju Pragash, Behaviour of low calcium flyash based geopolymer concrete structural elements with ggbs \& steel fibre, International Journal of Scientific Research Engineering \& Technology (IJSRET), Volume 2 Issue 11 pp 782-789 February 2014 www.ijsret.org ISSN $2278-0882$

[7] M. Adams Joe, A. Maria Rajesh, An Experimental Investigation on the Effect of Ggbs \& Steel Fibre in High Performance Concrete, International Journal of Computational Engineering Research, Vol- 04, Issue-4, pp 56-59. 